Institute of

Public Finance
NEWSLETTER

AN OGGASIONAL PUBLIGATION OF THE INSTITUTE OF PUBLIG FINANGE

\title{
EU-12: State aid before and after EU accession
}

IVANA JOVIĆ* Privredna banka Zagreb

\section{INTRODUGTION AND ABSTRACT}

State aid is one of the few areas, if not the only one, where the effects of a country's accession to the European Union (EU) can be clearly and unambiguously quantified. The data on movements in state aid for EU-I2 ${ }^{\mathrm{I}}$ Member States that joined the EU in 2004 and 2007 clearly show those effects, while providing a sound basis for an analysis and a forecast of how the accession process will affect state aid in Croatia (RC).

The main findings of the analysis of state aid movements in EU-I2 are the following:

- The EU accession process has obviously been the main driving force of state aid reforms in EU-I2.

- It has caused significant changes in the state aid policies of EU-I2 Member States, not only as concerns the size and structure of aid and allocation instruments, but also the perception and supervision of state aid objectives.

- While implementing common state aid rules issued by the European Commission, after accession the EU-I2 Member States continue to apply heterogeneous state aid policies, but to a much lesser extent than before the accession.

- Croatia already went through some of the accession experience of EU-I2 member countries over the last few years, but, according to Kesner-Škreb (2012), the bulk of adjust-

\footnotetext{
* The author is the Assistant Executive Director of the Office for Economic Research and Strategic Planning of Privredna banka Zagreb (PBZ).

The views expressed in this paper are those of the author and do not in any way represent the official positions or opinions of the institution with which she is employed.

I EU-I2 comprises new EU Member States (Bulgaria, Czech Republic, Estonia, Cyprus, Latvia, Lithuania, Hungary, Malta, Poland, Romania, Slovenia and Slovakia), and EUi5 comprises "old" Member States (Austria, Belgium, Denmark, Finland, France, Germany, Greece, Ireland, Italy, Luxembourg, the Netherlands, Portugal, Spain, Sweden and UK).
}

ment will occur immediately after joining the EU, and will be facilitated by a new European Commission's State Aid framework, scheduled to become effective in late 2013.

\section{SIZE AND STRUGTURE OF STATE AID IN THE NEW EU MEMBER STATES}

A comparison of state aid levels in EU-I2 several years before enlargement, namely in 2000 (EU-IO) and 2002 (Bulgaria and Romania) shows sharp deviations from the levels observed in EU-I5 Member States. The average state aid level in EU-I2 (I.2\% of GDP) was double the level in EU-I5 (O.6\% of GDP).

This was the consequence of the socialist management system in which state aid represented a key economic policy instrument. The state aid reform in Central and East European countries started with a transition to the market economy in the early I99os, i.e. the liberalisation of the then administratively determined prices, which led to the abolition of subsidies. However, substantial changes that followed the transition to the market economy negatively affected some industrial sectors (coal, steel, energy, manufacturing and agriculture), which prompted various forms of government intervention, i.e. subsidies, especially to enterprises with majority state ownership. Another step towards reducing aid followed in the mid-I99os, when the so-called Europe Agreements ${ }^{2}$ became effective and the EU-I2 Member States committed to adopt the EU legislation. An additional impetus to state aid modernisa-

2 The Europe Agreements with Hungary and Poland entered into force in 1994, with Bulgaria, Czech Republic, Romania and Slovakia in 1995, with Estonia, Latvia and Lithuania in 1998, and with Slovenia in I999. 


\section{Chart I}

State aid (excluding railways) as a percentage of GDP in 2000 (2002), EU-I5 and EU-I2

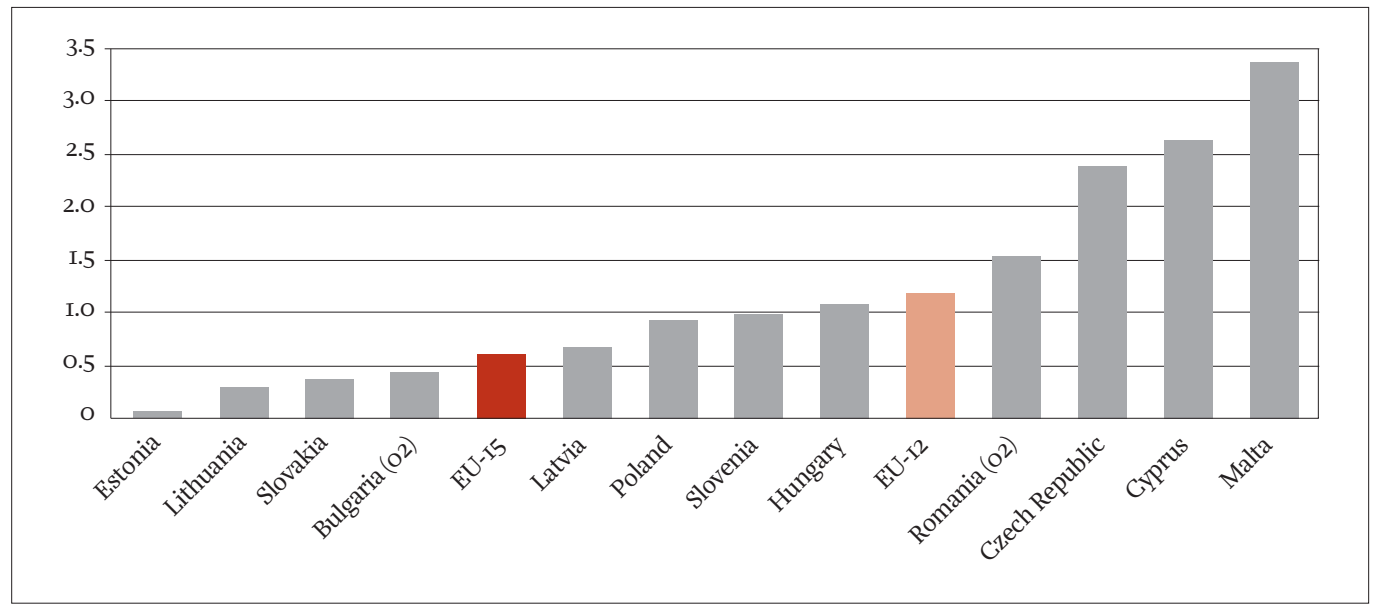

Source: European Commission (2012)

tion came from these countries' efforts to meet the accession criteria (Copenhagen criteria), namely to be functioning market economies with fully liberalised prices and to have capacity to cope with competition within the single EU market (Mulas-Granados, Koranchelian and SeguraUbiergo, 2008). Given the prominent role of state aid in creating a functioning market economy, the effective implementation and enforcement of the state aid policy proved to be the crucial element of the accession process.

The EU enlargement process has made a massive impact on state aid movements in EU-I2, by reducing the overall levels and changing the types of allocated aid. Chart 2 clearly shows the degree of reduction in the share of aid in GDP, up to I.9 structural points, observed in the EU-I2 Member States. The sharpest decline was seen in Czech Republic, while Hungary and Slovakia, for example, saw slight upturns, but with marked changes in the structure of aid, which will be further discussed later in the paper.

However, it is worth noting that the reduction in the level of aid was not linear from 2000 on, but it jumped to almost three times the average for EU-I5 immediately before the accession, i.e. in 2002 and 2003 (see Chart 3). Especially in 2002, state aid went up in Czech Republic, due to

\section{Chart 2}

State aid (excluding agriculture and transport ${ }^{3}$ ) as a percentage of GDP for EU-I2 before and after EU accession

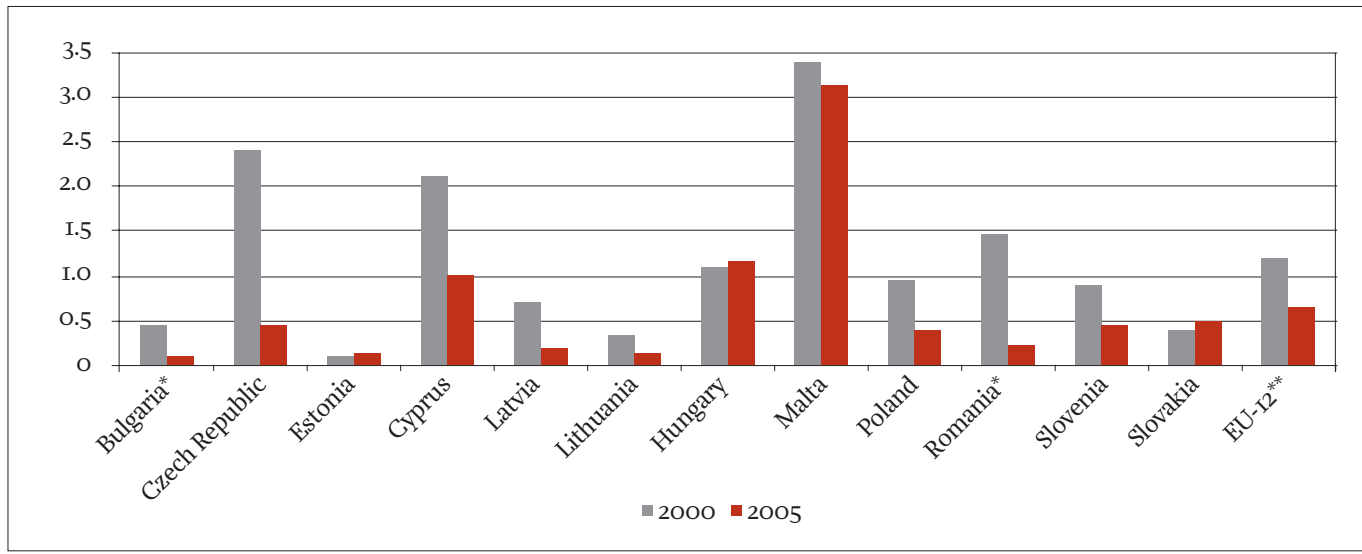

\footnotetext{
* Bulgaria and Romania, 2002 and 2007

** non-weighted average

Sources: European Commission (2012); author's calculation
}

3 Aid for agriculture and fisheries and for transport falls within the competence of DG Agriculture and DG Transport respectively. Therefore, these types of aid are not covered in the DG Competition's detailed presentations of state aid levels in the EU. 
the banking sector crisis, and in 2003, as a consequence of the coal mine restructuring. Some countries had obviously seized the opportunity to grant considerable amounts of state aid for the last time before the European Commission assumed control over that area. This actually shows how well they understood the EU state aid rules and the restrictions to be imposed by the EU Commission. After the accession, the state aid levels in EU-I2 fell dramatically, and, prior to the crisis in 2008, there was almost no difference between the averages for EU-I2 and EU-I5.

For most EU-I2 Member States, the accession has not only led to changes in the overall state aid level, but also to changes in its structure. Consequently, in line with the
EU rules, the share of sectoral aid decreased and the share of horizontal aid increased. The EU advocates "less but better state aid", i.e. aid targeted at horizontal objectives that have the least distorting effects on competition, and that is mainly aimed at research and development, small and medium-sized enterprises, environmental protection and education and training.

As shown on Chart 4, the structure of aid is changed drastically in favour of horizontal aid, the share of which increased (in Czech Republic, for example, from I4.4\% to 99.6\%). Slovakia was an exception, as it reported an increase in the share of sectoral aid and a decrease in hori-

\section{Chart 3}

State aid (excluding transport and agriculture) as a percentage of GDP in selected EU-I2 Member States

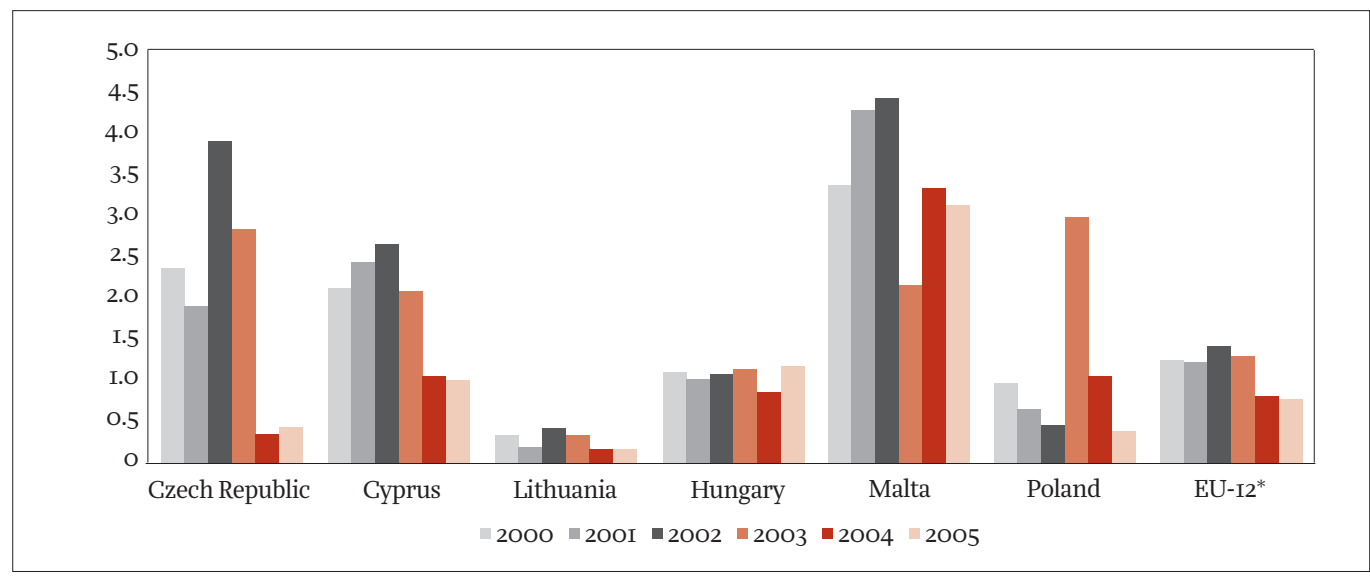

* non-weighted average

Sources: European Commission (2012); author's calculation

\section{Chart 4}

Structure of state aid (excluding transport and agriculture), 2000 and 2005, \%

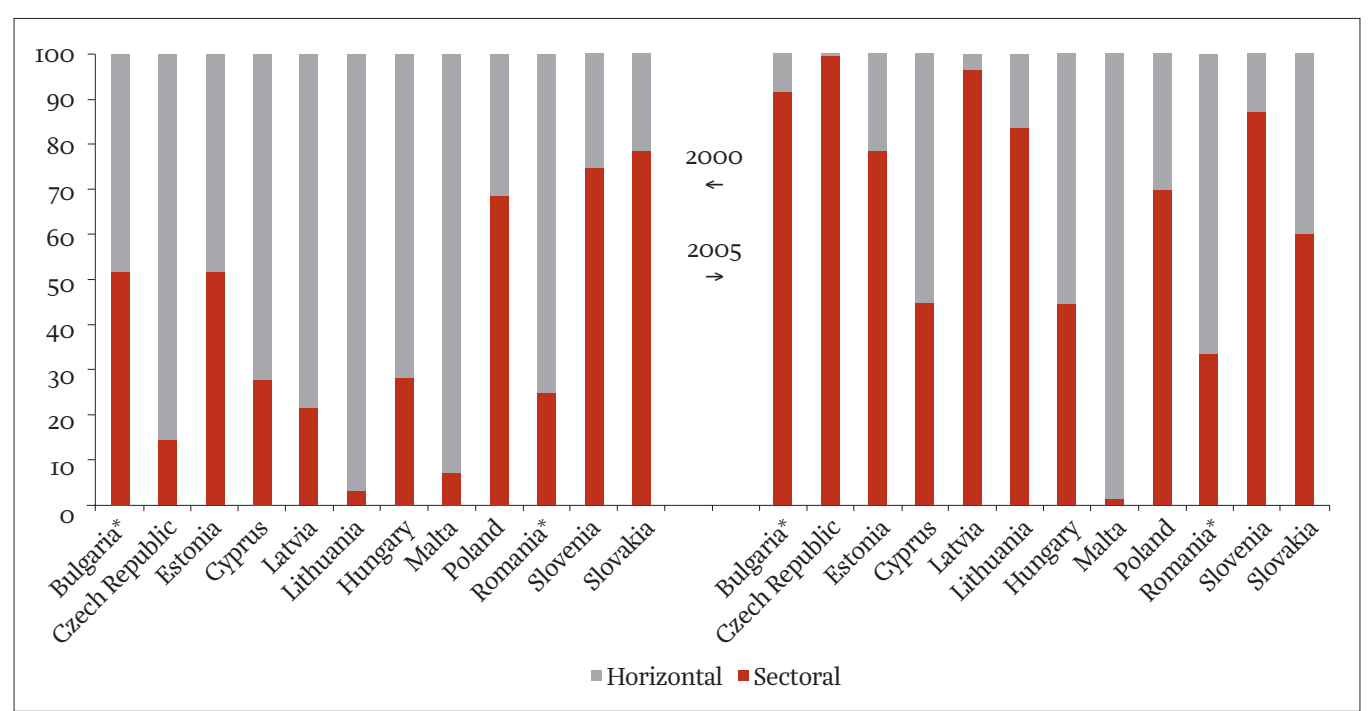

* Bulgaria and Romania, 2002 and 2007

Sources: European Commission (2012); author's calculation 
zontal aid during the reference period. However, the share of horizontal aid still predominated. As in the case of total level of aid, the growth of horizontal aid was not linear and its share even decreased in 2003, to increase again only after the EU accession (Blauberger, 2007). However, such movements are hardly surprising, given that the strong "demand" for sectoral aid in EU-I2 was due to the economic transition, when this aid was used as an important instrument for the restructuring and privatisation of state-owned enterprises, which helped mitigate the negative social consequences of these processes.

In the EU, state aid is mostly granted in the form of direct subsidies, which are considered a more transparent instrument than, for example, tax debt forgiveness. Hence,

\section{STATE AID POLIGY}

There are differences across EU-I2 Member States regarding the course of state aid reforms during the pre-accession period, depending on the purpose of aid. Thus, the overall level of aid declined faster in some countries than in others. In Slovakia and Poland, for example, the agricultural aid reform was vigorously opposed, while the reforms in other sectors went smoothly. Consequently, the final results of the reforms were also different.

While changes in state aid policies can be strongly related to the (anticipated) effects of the EU accession (and, after the accession, the control by the European Commission), domestic factors of influence in this area can by no means be ignored.

\section{Chart 5}

Structure of aid (to industry and services) by instrument (\%)

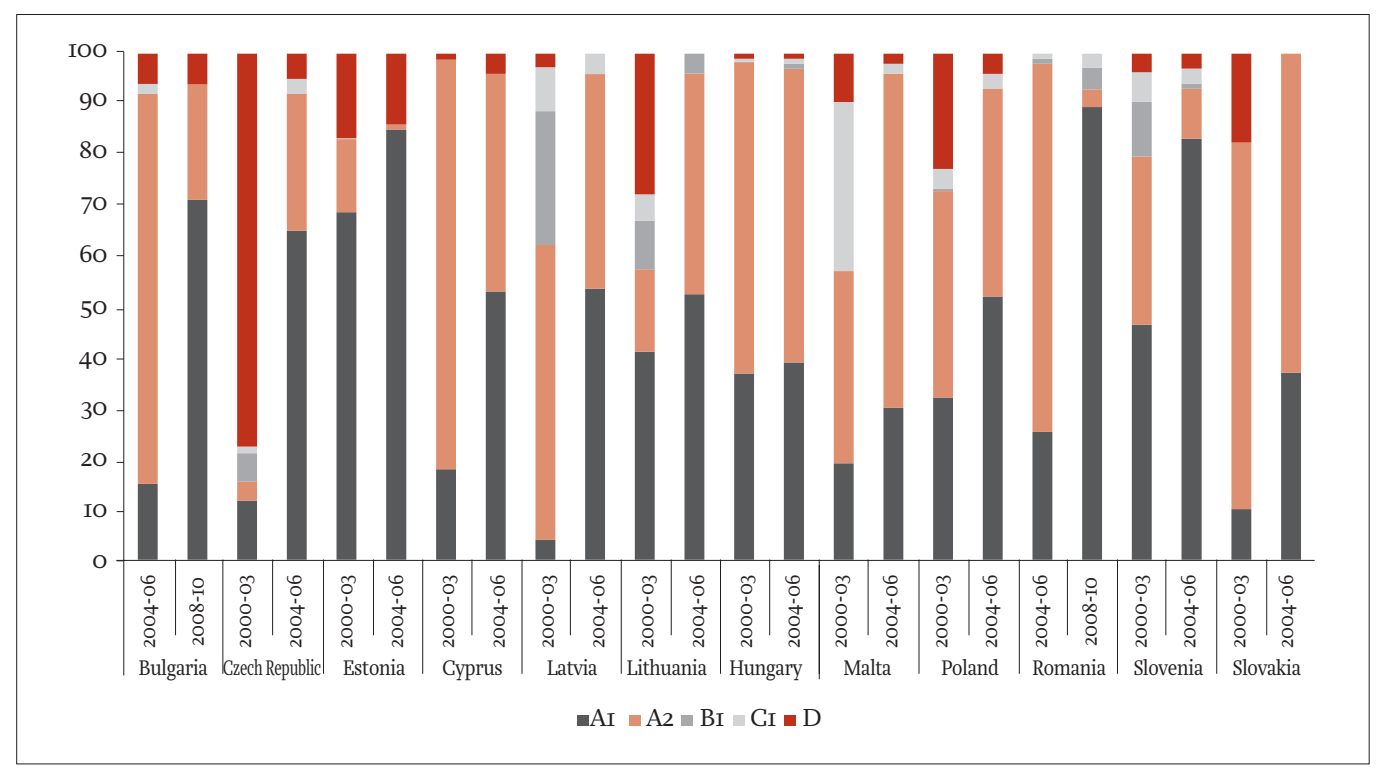

Sources: European Commission (2012); author's calculation

changes in the structure can also be observed in the state aid instruments ${ }^{4}$. A comparison between the periods before and after the EU accession shows that the change is in favour of subsidies, which predominate in the total structure (see Chart 5). In addition to subsidies, frequently used is also tax exemption and relief, which, for example in Slovakia, accounts for two thirds of total aid allocations. The shares of other instruments, such as equity participation, "soft" loans and state guarantees, decreased dramatically.

4 State aid instruments include: Ar subsidies, A2 tax exemption and relief, BI equity participation, CI "soft" loans and D state guarantees.
Mulas-Granados, Koranchelian and Segura-Ubiergo (2008) argue that the degree of external conditionality mainly explains differences in the reforms across types of aid. A high degree of external conditionality characterised all areas where the EU exerted strong pressures upon the EU-I2 Member States to comply with the acquis. In those areas where the EU pressure was stronger, domestic constraints (opposition to the reforms) played a less important role and the cross-country differences in the reforms were less pronounced. Domestic constraints may include the opposition from lobbies and trade unions, poor coordination between governments and regulatory agencies, the influence of political parties, etc. 
The state aid area is subject to strong external conditionality, as is considered the main component of the common market and market economy.

The cross-country differences in the reforms of individual types of state aid are explained by domestic constraints. Thus, as external conditionality weakens the influence of domestic constraints on the reform process becomes stronger. According to Mulas-Granados et al. (2008), there were generally four types of domestic constraints that affected the state aid reforms in the EU-I2 Member States: (I) unfavourable initial economic situation (low economic growth, high unemployment or inflation hampering the implementation of the reforms); 2) electoral constraints and power of domestic lobbies (the implementation of the reform was made difficult by relatively powerful groups affected by the reforms); 3) fragmented/decentralised decision-making system that created problems in coordination and authority and thus complicated the reform process; and (4) weak independent regulators (the reform was less successful in countries in which regulators were weak and had no price-setting power, e.g. in the energy sector).

As indicated in Mulas-Granados, Koranchelian and Segura-Ubiergo (2008), in most cases, the outcome of the reform can be explained as a combination of external conditionality and domestic political constraints.

\section{Table I}

Some cases of state aid reform in EU-I2

\begin{tabular}{|c|c|c|}
\hline \multirow{2}{*}{$\begin{array}{l}\text { Domestic } \\
\text { constraints }\end{array}$} & \multicolumn{2}{|c|}{ External conditionality } \\
\hline & high & low \\
\hline \multirow[b]{2}{*}{ high } & State aid reform in Cyprus & $\begin{array}{l}\text { Energy subsidy reform } \\
\text { in Hungary }\end{array}$ \\
\hline & State aid reform in Malta. & $\begin{array}{l}\text { Transport subsidy } \\
\text { reform in Czech } \\
\text { Republic }\end{array}$ \\
\hline \multirow{2}{*}{ low } & $\begin{array}{l}\text { Agricultural subsidy } \\
\text { reform in Slovakia }\end{array}$ & $\begin{array}{l}\text { Energy subsidy reform } \\
\text { in Romania }\end{array}$ \\
\hline & $\begin{array}{l}\text { Agricultural subsidy } \\
\text { reform in Poland }\end{array}$ & $\begin{array}{l}\text { Transport subsidy } \\
\text { reform in Estonia }\end{array}$ \\
\hline
\end{tabular}

Source: Mulas-Granados, Koranchelian and Segura-Ubiergo (2008)

In the cases when both the degree of external conditionality and domestic constraints were high, the reform was successful. However, such countries were often granted some transitional arrangements when joining the EU. When the degree of external conditionality was high and the strength of domestic constraints was low, the reform was implemented without transitory arrangements. When the degree of external conditionality was low and the strength of domestic constraints high, the reform was limited and incomplete. When both the degree of external conditionality and the strength of domestic constraints were low, the reform only occurred as a result of previous policy failure and strong domestic consensus and commitment to carry out the reform.

\section{Energy subsidy reform in Hungary and transport subsidy reform in the Gzech Republic}

The energy subsidy and transport subsidy reforms in Hungary and Czech Republic respectively provide the best examples of reforms with low external conditionality and high domestic constraints. In both countries, the governments tried to comply with the minimum EU requirements with respect to opening their markets to EU companies, but political interference blocked the reforms. In Hungary, the reform process was slowed down due to disputes between the government and the independent regulator, while in the Czech Republic, disputes among the government, the transport company and trade unions reduced the scope of reform.

With this concept in mind, it would be interesting to see the results of negotiations for the EU-I2 Member States and the areas in which they obtained transitional arrangements.

During the accession negotiations, six out of ten countries negotiated transitional arrangements for state aid reform, and all of them accepted the three-year transitory period before moving to the Common Agricultural Policy system.

The accession process started in 1998, by determining the conditions for joining the EU for each country. The accession negotiations were conducted to lay down the terms under which the accession candidates had to accept, enforce and apply the acquis communautaire, i.e. detailed legislation and rules adopted on the basis of the Treaty Establishing the European Community, and granted transitional arrangements, limited in scope and duration. In practice, each EU-I2 Member State established a state aid monitoring authority, which screened the award of public resources to determine whether it constituted state aid as defined in Article 87 of the EC Treaty, and whether it was compatible with the common market. Where state aid was identified as incompatible with the EU acquis, countries were supposed to adapt it to the EU standards, abolish it or gradually reduce it. The first noticeable progress in the area of state aid came as late as 2000/OI, and the negotiations were completed in December 2002.

During the negotiation process, two types of aid proved particularly problematic. The first was fiscal aid that was incompatible with Article 87 of the Treaty and included various forms of tax relief used to attract foreign investment. The second was aid used to rescue enterprises in difficulties, by means of instruments like tax debt relief or guarantees. Negotiations on transitory periods were 
Table 2

Agreed transitional measures and their effects

\begin{tabular}{|c|c|c|}
\hline County & Agreed & Effects \\
\hline Cyprus & The abolition of incompatible fiscal aid by end-2005. & $\begin{array}{l}\text { The level of state aid fell from } 1.6 \% \text { of } \\
\text { GDP in } 2004 \text { to } 0.6 \% \text { of GDP in } 2006 \text {. }\end{array}$ \\
\hline Czech Republic & The steel sector restructuring to be completed by 3I. Dec. 2006. & $\begin{array}{l}\text { The share of sectoral aid decreased } \\
\text { sharply, from } 88 \% \text { in } 2003 \text { to } 0.2 \% \text { in } \\
2007 \text {. }\end{array}$ \\
\hline \multirow{4}{*}{ Hungary } & $\begin{array}{l}\text { The phasing out of incompatible fiscal aid to small and medium-sized enterprises } \\
\text { by end-2oII. }\end{array}$ & \multirow{4}{*}{$\begin{array}{l}\text { The level of state aid fell from } 2.8 \% \text { of } \\
\text { GDP in } 2004 \text { to I.9\% of GDP in } 2007 \text {. In } \\
\text { addition, the share of sectoral aid de- } \\
\text { creased from } 61 \% \text { in } 2003 \text { to } 54 \% \text { in } 2007 .\end{array}$} \\
\hline & $\begin{array}{l}\text { The replacement of incompatible fiscal aid to large enterprises by regional } \\
\text { investment aid; the aid is limited to a maximum of } 75 \% \text { or } 50 \% \text { of eligible invest- } \\
\text { ment costs, depending on the date of investment commencement; in the road } \\
\text { vehicle manufacturing sector, aid is additionally limited to } 30 \% \text { or } 20 \% \text { of eligible } \\
\text { investment costs. }\end{array}$ & \\
\hline & The phasing out of incompatible fiscal aid to off-shore companies by end-2005. & \\
\hline & $\begin{array}{l}\text { The phasing out of incompatible fiscal aid, granted by local authorities, by end- } \\
2007 .\end{array}$ & \\
\hline \multirow{4}{*}{ Malta } & $\begin{array}{l}\text { The phasing out of incompatible fiscal aid to small and medium-sized companies } \\
\text { by end-2oII. }\end{array}$ & \multirow{4}{*}{$\begin{array}{l}\text { The level of state aid fell from } 3.7 \% \text { of } \\
\text { GDP in } 2004 \text { to } 2.4 \% \text { of GDP in } 2007 \text {. The } \\
\text { share of sectoral aid also decreased from } \\
94 \% \text { in } 2004 \text { to } 77 \% \text { in } 2009 \text {. }\end{array}$} \\
\hline & $\begin{array}{l}\text { The replacement of incompatible fiscal aid to large enterprises by regional } \\
\text { investment aid; the aid is limited to a maximum of } 75 \% \text { or } 50 \% \text { of eligible invest- } \\
\text { ment costs, depending on the date of obtaining tax exemption. }\end{array}$ & \\
\hline & Shipyard restructuring aid during the restructuring period (by end- 2008). & \\
\hline & The phasing out of operating aid under the Business Promotion Act by end-20o8. & \\
\hline \multirow{5}{*}{ Poland } & The phasing out of incompatible fiscal aid to small enterprises by end-2oII. & \multirow{5}{*}{$\begin{array}{l}\text { The level of aid was reduced from } 1.4 \% \text { of } \\
\text { GDP in } 2004 \text { to o.6\% of GDP in } 2007 \text {. The } \\
\text { share of sectoral aid also decreased from } \\
75 \% \text { in } 2004 \text { to } 14 \% \text { in } 2007 \text {. }\end{array}$} \\
\hline & $\begin{array}{l}\text { The phasing out of incompatible fiscal aid to medium-sized enterprises by end- } \\
\text { 20IO. }\end{array}$ & \\
\hline & $\begin{array}{l}\text { The replacement of incompatible fiscal aid to large enterprises by regional } \\
\text { investment aid, to be limited to a maximum of } 75 \% \text { or } 50 \% \text { of eligible investment } \\
\text { costs, depending on the date of obtaining permit; in the motor vehicle manufac- } \\
\text { turing sector, the aid is additionally limited to } 30 \% \text { of eligible investment costs. }\end{array}$ & \\
\hline & $\begin{array}{l}\text { In the area of environmental protection aid, standard investments are allowed, } \\
\text { for which a transition period has been agreed under the Environmental chapter; } \\
\text { during this period the level of aid may not exceed the upper limit of regional aid. }\end{array}$ & \\
\hline & The steel sector restructuring to be completed by 3І Dec. 2006. & \\
\hline \multirow{2}{*}{ Slovakia } & $\begin{array}{l}\text { The replacement of incompatible fiscal aid to beneficiaries in the manufacturing } \\
\text { of road vehicles by regional investment aid; the aid is limited to a maximum of } \\
30 \% \text { of eligible investment costs. }\end{array}$ & \multirow{2}{*}{$\begin{array}{l}\text { The level of state aid decreased from } \\
\text { o.6\% of GDP in } 2004 \text { to } 0.4 \% \text { of GDP } \\
\text { in } 2007 \text {. The share of sectoral aid also } \\
\text { decreased, from } 28 \% \text { in } 2003 \text { to } 10 \% \text { in } \\
2009 \text {. }\end{array}$} \\
\hline & $\begin{array}{l}\text { The suspension of incompatible state aid for a beneficiary in the steel sector at } \\
\text { end-20og or upon reaching the previously determined amount of aid, whichever } \\
\text { occurs first. }\end{array}$ & \\
\hline
\end{tabular}

Source: European Commission (2003)

based on the principle that they should be limited in the scope and duration. Estonia, Lithuania, Latvia and Slovenia did not apply for transition arrangements.

\section{HETEROGENEITY OF STATE AID AS A RESULT OF POLIGY DIFFERENGES}

As shown in Table 3, there are three subgroups of EU-I2 Member States with respect to the overall level and purpose of state aid, each applying a similar state aid policy. Depending on the combination o a state aid level and the share of horizontal aid in total aid, four types of state aid policy can be distinguished, but examples for only three subgroups can be identified in practice.

Some EU-I2 countries like Estonia (but also Latvia and Lithuania) allocated no substantial funds for state aid even

\section{Table 3}

Types of state aid policy

\begin{tabular}{llll} 
& & $\frac{1}{\text { low }}$ & \multicolumn{1}{c}{ high } \\
$\begin{array}{l}\text { share of } \\
\text { horizontal } \\
\text { aid }\end{array}$ & large & $\begin{array}{l}\text { Estonia, Czech } \\
\text { Republic (after acc.) }\end{array}$ & Slovenia \\
\cline { 3 - 4 } & small & - & $\begin{array}{l}\text { Poland, Czech } \\
\text { Republic (before } \\
\text { acc.) }\end{array}$ \\
\hline
\end{tabular}

Source: Blauberger (2007)

before the accession, and if they did, they have mainly been intended for horizontal aid. These countries faced no major changes in the state aid policy, either immediately after the accession or during the last few years. 
The second group comprises countries where the use of state aid has been slightly heavier than in the first group, but again mostly for horizontal purposes. These countries include Slovenia and Slovakia; they also experienced no significant changes in either the level or structure of state aid.
The third group consists of countries with high levels of state aid, which is mainly targeted at particular economic sectors, such as Poland, Hungary, Malta and Cyprus. Bilateral negotiations with these countries therefore resulted in a series of aforementioned transitional arrangements.

\section{Chart 6}

Groups of EU-I2 Member States by state aid policy (excluding transport and agriculture) before EU accession, 2000-04 average (2002-06 for Bulgaria and Romania)

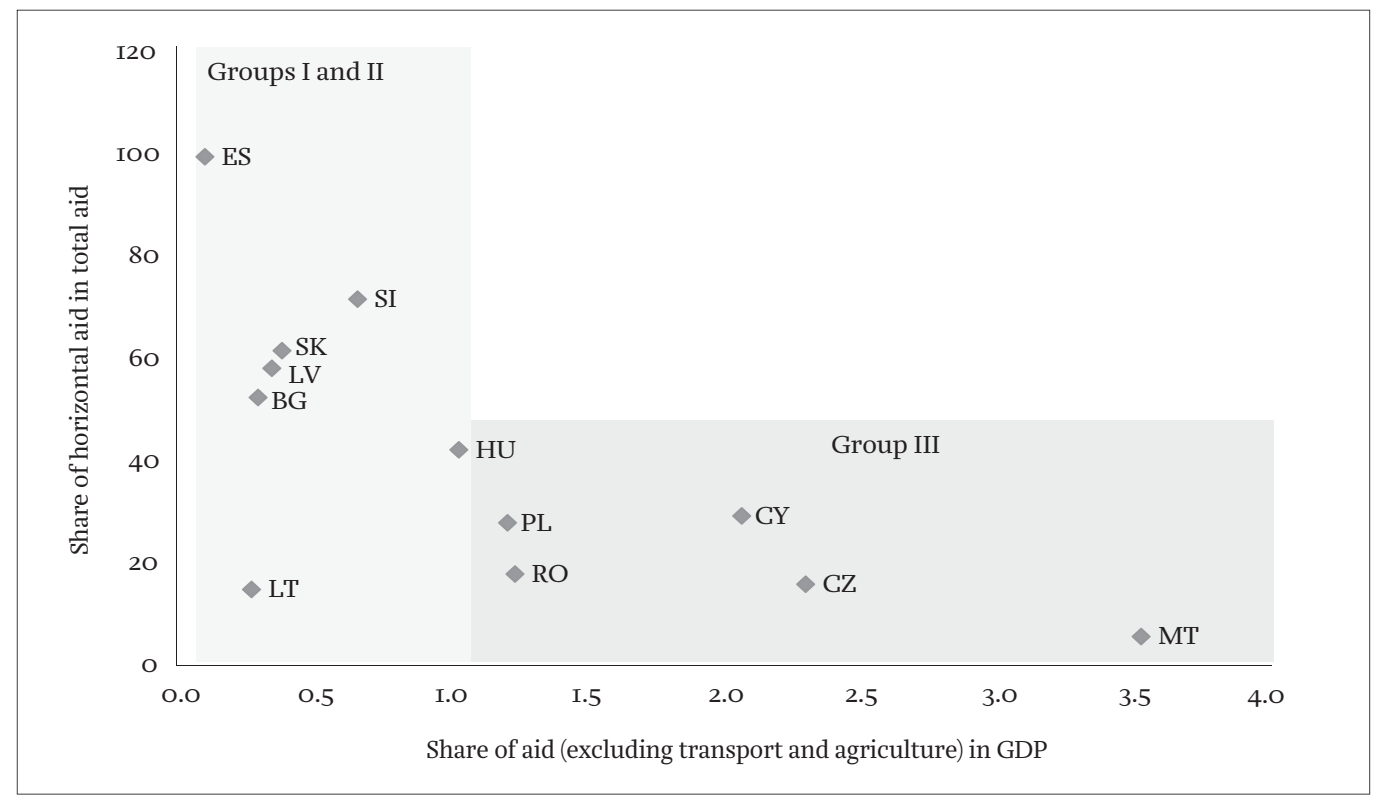

Sources: European Commission (20I2); and autor's calculation

\section{Chart 7}

Groups of EU-I2 Member States by state aid policy (excluding transport and agriculture) after EU accession, 2005-IO average (2007-Io for Bulgaria and Romania)

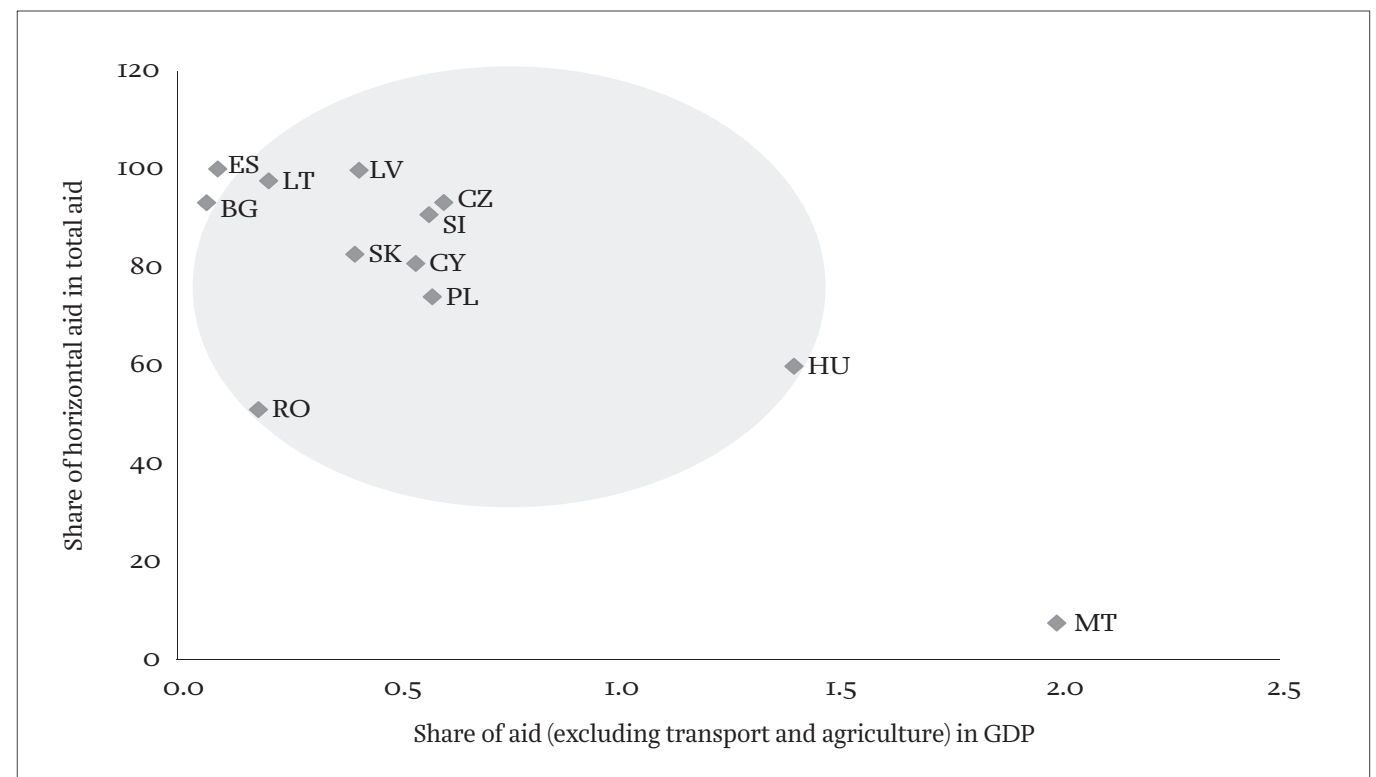

Sources: European Commission (2012); and autor's calculation 
This group has experienced the most fundamental changes, in terms of both the level and structure of aid. However, heterogeneous movements are still observable within this group.

While the accession process obviously contributed to a reduction in the overall levels of state aid, but also to an increase in the share of horizontal aid in overall aid, the countries remained relatively heterogeneous with respect to these two indicators, but within a narrow range.

\section{STATE AID REFORM IN THE EU}

The Europe 2020 Strategy recognises the importance of state aid and its potential for contributing, actively and positively, to the strategy goals, by supporting initiatives to promote innovative, efficient and environmentally friendly technologies through facilitated access to investment state aid, risk capital and R\&D funding.

Modernisation of state aid control should facilitate the assessment of well-designed aid targeted at market failures and objectives of common interest, as well as aid that has the least distortive effect on competition ("good aid"). The reform of the state aid control is necessary in order to improve the quality and effectiveness of public spending by granting state aid, with the ultimate goal of promoting the common market growth, and the prerequisite for this is the functioning of competition. State aid that is not targeted at market failures and has no stimulating effect does not only constitute a waste of public resources, but it poses an obstacle to growth by distorting market competition.

While emphasis is placed on the quality and efficiency of state aid, the modernisation of its control and a better use of taxpayers' money will help Member States strengthen budgetary discipline and improve the quality of public finance. This is particularly important for achieving effective fiscal consolidation, which establishes a link between the role of targeted public spending in stimulating growth, and the need for budget expenditure control.

Hence, the objectives of the modernisation of state aid control are threefold: (I) to promote sustainable, smart and inclusive growth of the competitive internal market; (2) to focus the European Commission's attention beforehand on cases with the strongest impact on the internal market; and (3) to streamline rules and facilitate decisionmaking.

Such improved state aid control would support sustainable growth and raise the quality of public spending, while discouraging aid that brings no real value added and distorts competition. In line with these objectives, the Eu- ropean Commission has been developing common principles for assessing the compatibility of national state aid and will revise and streamline some regulations currently in force, such as the Guidelines on Environmental Aid, on Regional Aid and on Risk Capital, but also guidelines on rehabilitation and restructuring of enterprises.

Within the modernisation process, the Commission has recently published a draft regulation on small-value (de minimis) aid, increasing the aid threshold from EUR IOO,OOO to EUR 200,000 and exempting aid below this level form the requirement to notify the European Commission. After public consultations, the new regulation should enter into force in late 20I3, which is also the envisaged date of application of all regulations to be amended during the state aid modernisation process.

\section{LITERATURE:}

Blauberger, M., 2007. European State Aid Control in the New Member States - The Examples of Poland and the Czech Republic. Bremen: University of Bremen, Jean Monet Centre for European Studies.

European Commission, 2003. The Treaty of Accession 2003. Available from: [http://ec.europa.eu/enlargement/archives/enlargement_process/future_prospects/negotiations/euio_bulgaria_romania/treaty_ 2003/content/index_en.htm].

European Commission, 2004. State Aid Scoreboard autumn 2004 update. Brussels, September I6, 2004. COM (2004)750 final. Available from: [http://ec.europa.eu/competition/state_aid/studies_reports/archive/2004_autumn_en.pdf].

European Commission, 2005. State Aid Scoreboard autumn 2005 update. Brussels, December 9, 2005. $\operatorname{COM}(2005) 624$ final. Available from: [http://ec.europa.eu/competition/state_aid/studies_reports/archive/2005_autumn_en.pdf].

European Commission, 2006. State Aid Scoreboard autumn 2006 update. Brussels, December II, 2006. $\operatorname{COM}(2006) 76$ I final. Available from: [http://ec.europa. eu/competition/state_aid/studies_reports/archive/2006_autumn_en.pdf].

European Commission, 2007. State Aid Scoreboard autumn 2007 update. Brussels, December 3I, 2007. COM (2007)79I final. Available from: [http://ec.europa.eu/competition/state_aid/studies_reports/archive/2007_autumn_en.pdf].

European Commission, 2008. State Aid Scoreboard autumn 2008 update. Brussels, September I7, 2008. COM (2008)75I final. Available from: [http://ec.europa.eu/competition/state_aid/studies_reports/archive/2008_autumn_en.pdf]. 
European Commission, 2009. Facts and figures on State aid in the EU Member States. Commission Staff Working Document. Brussels December 7, 2009. SEC(2009) I638. Available from: [http://ec.europa.eu/competition/state_aid/studies_reports/archive/annex_ 2009_autumn_en.pdf].

European Commission, 2010. Facts and figures on State aid in the EU Member States. Commission Staff Working Document. Brussels December I, 20IO. SEC(2OIO) I462. Available from: [http://eur-lex.europa.eu/LexUri Serv /LexUriServ.do?uri=SEC:2OIO:I462:FIN:EN:PDF].

European Commission, 2012a. Scoreboard - Data on state aid expenditure. Available from: [http://ec.europa. eu/competition/state_aid/studies_reports/expenditure.html].

European Commission, 2012b. State Aid Modernisation. Available from: [http://ec.europa.eu/competition/ state_aid/modernisation/index_en.html].

Kesner-Škreb, M., 20I2. "What will happen to state aid in Croatia after EU accession?”. Newsleter, no. 70. Available from: [http://www.ijf.hr/upload/files/file/ENG /newsletter/70.pdf].

Mulas-Granados, G., Koranchelian, T. and Segura Ubiergo, A., 2008. "Reforming Government Subsidies in the New Member States of the European Union”. IMF Working paper, WP/o8/I65. Washington: International Monetary Fund. 